\title{
DYNAMICS OF DIPHTHERIA INCIDENCE IN THE TRANSCARPATHIAN REGION OF UKRAINE IN THE VACCINATION ERA
}

DOI: 10.36740/WLek202104139

\author{
Yelyzaveta I. Rubtsova', Svitlana V. Oberemko ${ }^{2}$, Maryana M. Rosul' \\ 'UZHGOROD NATIONAL UNIVERSITY, FACULTY OF POSTGRADUATE AND PRE-UNIVERSITY EDUCATION, UZHGOROD, UKRAINE \\ 2TRANSCARPATHIAN REGIONAL LABORATORY CENTER OF THE MINISTRY OF HEALTH OF UKRAINE, UZHGOROD, UKRAINE
}

\begin{abstract}
The aim: Was to study the dynamics of the incidence of diphtheria in the Transcarpathian region of Ukraine.

Materials and methods: A retrospective analysis of the data of the state statistical reporting of the Transcarpathian region on the incidence of diphtheria, the carriage of infection, vaccination coverage and the severity of diphtheria immunity was carried out.

Conclusions: Low coverage of the population with vaccination against diphtheria, registration of an outbreak of diphtheria among international students of the region, and other regions of Ukraine in conditions of increased population migration, are alarming prognostic signs of the possible development of another significant epidemic rise of diphtheria morbidity in Transcarpathia.
\end{abstract}

KEY WORDS: diphtheria, morbidity, carrier, epidemic, vaccination

Wiad Lek. 2021;74(4):1019-1023

\section{INTRODUCTION}

Diphtheria is a dangerous infectious disease with a high mortality and disability rate. The source of infection is a sick person or a bacteria carrier of toxigenic strains, sick children and adults who do not have antitoxic immunity, including those vaccinated with low antibody titers. from The case-fatality rate from diphtheria is $5-17 \%$, even in individuals receiving proper care and treatment. [1] This figure can reach $20 \%$ in children under five years of age and adults over 40 years. [2]

Mass immunization of the population against diphtheria, which has been carried out since the mid-50s of the last century, has contributed to a sharp decline in the pathogen's incidence and bacteria carriers. However, diphtheria outbreaks, although rare, still occur worldwide in the last decade as in India, Nigeria, in refugee resettlement centers in Bangladesh, in Yemen and other Middle East countries. $[3,4,5,6,7]$

Diphtheria remains endemic in many areas with limited vaccination coverage. In 2018, the WHO recorded 16,611 reported cases. Generally, diphtheria is under-reported from many regions, including Asian, African and Eastern Mediterranean countries. [8]

The epidemiology of diphtheria is constantly changing owing to varying prevalence of Corynebacterium spp. in different regions, travel and migration, variations in socioeconomic status and vaccination rates and other factors. Humans are the only known natural host for C. diphtheria. $[2,8]$ Though the toxigenic strain Corynebacterium ulcerans has been increasingly identified as an etiological agent in Western Europe, whereas disease associated with it is of zoonotic origin (from domestic and wild mammals). High-resolution molecular typing of strains is vital to identify disease transmissions and outbreaks. $[2,9,10]$

At the end of the last century, there were two diphtheria waves in Europe: in 1982-1985 and 1990-1999. [1] The largest outbreak in recent years occurred between 1990 and 1998 in the states of the former Soviet Union. More than 158,000 cases of diphtheria were reported in post-Soviet countries between 1990 and 1999, of which 4,000 were fatal $[11,12]$

In Ukraine, there were more than 20,000 diseases, 700 deaths and 13,204 cases of carriers of toxigenic strains of the pathogen detected during this period. The emergence of the epidemic was facilitated by the low level of coverage of children and adults with preventive vaccinations. The diphtheria vaccination rate declined significantly in the early 1990s due to political unrest after the collapse of the Soviet Union. This has led to an explosive increase in morbidity and mortality from this infection. Lack of caution about diphtheria (many primary care physicians have not encountered it before) and lack of physicians' awareness have led to delays in diagnosing and treating patients. [11]

Simultaneously, all types of migration processes in Ukraine have significantly intensified in recent decades, according to the National Report of the Institute of Demography and Social Research of the Academy of Sciences of Ukraine. [13] This process is highly typical for Transcarpathial region of Ukraine too. [14]

The epidemic process of diphtheria in mass vaccination conditions is manifested by sporadic cases of diseases and 
registration of bacteria carriers. Laboratory bacteriological diagnosis is a leading factor in the epidemiological surveillance of diphtheria. Undetected and untreated carriers of the pathogen create conditions for the spread of infection. The high proportion of vaccinated does not prevent colonisation by the pathogen of the nasopharyngeal mucosa, so it is important to conduct screening studies to maximise the detection and remediation of carriers of C. diphtheria. The majority of carriers are carriers of nontoxigenic strains, some of which have the toxigenic gene. $[2,8]$

The frequency of detection of bacteria carriers in the post-epidemic period decreases every year. A serious harbinger of the diphtheria epidemic of the 1990s was the increase in the registration of carriers of toxigenic strains of the pathogen. The ratio of patients with diphtheria to carriers 1:2 and more indicates latent morbidity due to increased carriers and errors in diagnosis. [15]

The study of the epidemiological significance of the detected carrier of diphtheria in Kiyiv in 1989-1998 showed that the levels of carriers of toxigenic and nontoxigenic strains of C. diphtheria differed significantly among different groups of the population. The highest group of epidemic risk were patients with pathology of the nose and throat. [15] Before the beginning of the epidemic in 1991, there was a spread of nontoxigenic strains of C. diphtheria. The beginning of the epidemic coincided with the beginning of an increase in the intensity of circulation of toxigenic strains of the pathogen in the population. $[15,16]$

Selective genetic studies of non-toxigenic strains of the diphtheria pathogen found that $7-10.5 \%$ of them had a toxigenicity gene and were able to cause disease. And in 1999 in Ukraine in $17.3 \%$ of patients with diphtheria were isolated nontoxigenic strains of the pathogen. The largest number of such strains was registered in patients diagnosed with diphtheria in Kyiv, where out of 90 initially examined patients, in 43 nontoxic strains were identified $(47.8 \%)$. [11,13,14]

Therefore, all such phenotypically nontoxigenic strains were recommended for study by the polymerase chain reaction method for in-depth investigation and identification of the possible toxigenicity gene. $[2,8]$

According to the Ukrainian Center of the State Sanitary and Epidemiological Surveillance, over the last 20 years, there has been a decrease in diphtheria registration, even against the background of a significant decrease in the volume of preventive vaccinations. In some cases, this was probably due to the "cure" of diphtheria with modern antibiotics in the early catarrhal period of the disease and the removal of the previous diagnosis of "diphtheria" in the absence of a positive microbiological study. There were cases when in patients with a negative bacteriological examination the diagnosis of diphtheria was removed and clarified for the diagnosis of "Follicular tonsillitis" in the existing clinical picture and specific treatment of the patient (introduction of diphtheria serum), which led to artificial reduction of morbidity [15].

In the system of epidemiological surveillance of diphtheria, immunoprophylaxis is the most effective measure. According to the vaccination calendar, coverage of the population with preventive vaccinations has decreased from year to year for the last three decades. This process was due to untimely and irregular delivery of immunobiological drugs. $[11,17,18]$ Anti-vaccine propaganda and refusal to vaccinate, untimely vaccination, violation of vaccination deadlines also contributed to that. [18] As a result, the number of immunologically vulnerable to diphtheria population and likelihood of epidemic outbreaks is increased in the country. These processes prompted us to study this issue in our region.

\section{THE AIM}

The aim was to investigate the peculiarities of the diphtheria epidemic process in the Transcarpathian region of Ukraine in the era of vaccination.

\section{MATERIALS AND METHODS}

The study material was indicators of diphtheria incidence, carriers of the bacteria, diphtheria vaccination coverage and the results of studies of diphtheria herd immunity in the Transcarpathian region from the following sources of information:

1. Official site of the main department of statistics in the Transcarpathian region. http://database.ukrcensus.gov. ua

2. State statistical reporting form №2 "Report on individual infections and parasitic diseases" in the Transcarpathian region for 2000-2020.

3. Sectoral reporting f.№ 40 of the Transcarpathian Regional Sanitary and Epidemiological Service and the Laboratory Center of the Ministry of Health of Ukraine for 2010-2020.

4. State statistical reporting on preventive vaccinations (Form 70) for 2010-2020.

5. Computerized reporting program on preventive vaccinations "UKRVAK" in the Transcarpathian region for 2010-2020.

The study data were processed using a comprehensive epidemiological method (CEM), including descriptive-evaluative, analytical methods and forecasting. A retrospective epidemiological analysis was performed. Data from a complex of bacteriological and serological tests were used.

\section{REVIEW AND DISCUSSION}

Since the introduction of state registration of infectious diseases in the Transcarpathian region (1946), diphtheria's dynamics was wavy. For the period 1946-1959, the figures ranged from 41.2 per 100.000 population (328 cases) in 1948 to 13.7 (120 cases) in 1955. During the 1960s and 1980s, against the background of mass coverage of the pediatric population with diphtheria vaccination, the incidence was sporadic, but cases were registered annually. The highest incidence of diphtheria in this period was observed in 1986 and 1987, 0.08 and 1.2 per 100 thousand people, respectively. (see Figure 1) 


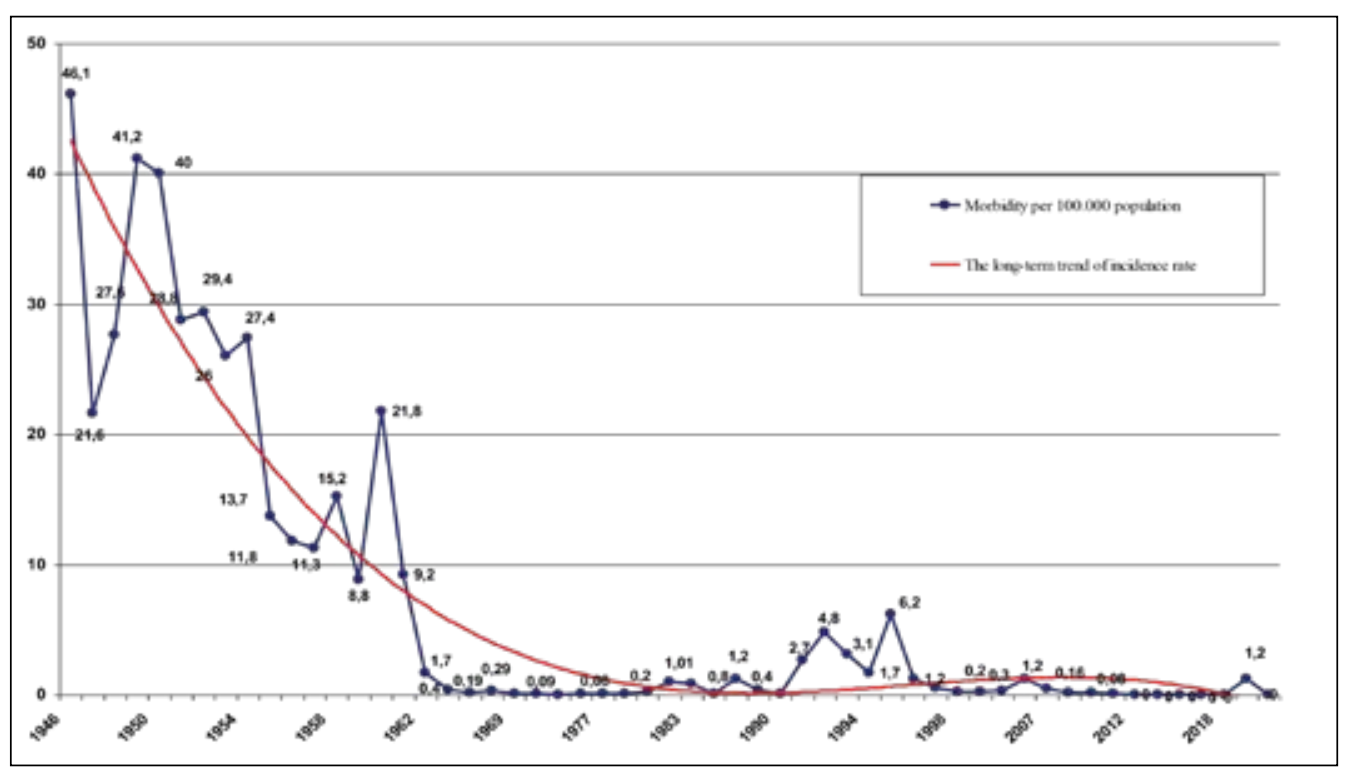

Fig. 1. Dynamics of the incidence of diphtheria (per 100.000 population) and its tendency in the Transcarpathian region for the period 1946-2020
Within the epidemic rise in diphtheria in the 90s of the last century in Transcarpathia, 266 cases of the disease were registered, including 96 in children under 14 years (42.5\%), and 7 deaths (3.1\%). During this period, 956 carriers of toxigenic strains of diphtheria were detected, including 322 in children (33.7\%). The highest rates of disease at this time were observed in 1992 (61 cases, 4.8 per 100.000 population) and 1995 (79 cases, 6.2 per 100.000 population, the peak of the last epidemic).

In 2000-2004, no diphtheria disease was detected. Then 25 cases of infection were diagnosed within 2005-2011. Intensive incidence rates ranged from 0.16 to $1.2 \mathrm{per}$ 100.000 people.

Simultaneously, no diphtheria carrier was found among 51,454 people examined for tonsillitis and other otorhinolaryngological pathology. Healthy individuals were also examined for prophylactic purposes before admission to closed organized groups.

In 2019, a diphtheria outbreak was registered again - 15 cases.

This happened in the fall of 2019 in Uzhgorod among foreign students from India. 15 people fell ill. The diagnosis of patients was: Diphtheria of the tonsils, localized, islet form, gram + strain Corynebacterium Mitis, toks-. One patient had a course of moderate severity; others had a mild course of the disease.

According to the results of molecular genetic studies of selected cultures of Corynebacterium diphtheriae specific fragments of nucleic acids of the diphtheria toxin gene were found in three patients.

Of the 15 patients, 14 were identified actively during a set of anti-epidemic measures for the first patient. The source of infection of the first patient is unknown. However, shortly before the disease, he was temporarily in other countries (Germany, Israel, India). All patients had no documented evidence of diphtheria vaccination.

106 contacts were surveyed and no carrier was invented. No patients or carriers were found among the local population.
In total, 16,007 people, including 2,848 university students, were vaccinated against diphtheria during the period of localization and elimination of the outbreak in the city of Uzhgorod.

The dynamics of diphtheria carriers' detection for the period 1990-1999 in the Transcarpathian region was characterized by the highest level in 1993-1995 (11.1-12.5 per 100.000 population) The average annual level of carriers for this period was 3.67 per 100 thousand people. The next decade (2000-2010) decreased 3.7 times to 0.98 per 100 thousand people. 3 carriers of nontoxigenic strains of the diphtheria pathogen were identified in 2010-2020.

During 2010-2020, bacteriological laboratories of the Sanitary and Epidemiological Service and medical institutions in Transcarpathian region examined 75068 (18+, $0,02 \%$ ) people, of whom $69,9 \%$ for diagnostic purposes, $4,9 \%$ - for epidemic indications and $25,2 \%$ - for prophylactic purposes. On average, 7.5 thousand people are examined annually.

Coverage of the region's population by planned preventive vaccinations against diphtheria for 2010-2018 was deficient. The most critical situation was in 2015; then vaccination plan was implemented by only $7.2 \%$. It's necessary to note that this was mainly due to the adult population's low vaccination coverage with fluctuations from 0 in 2015 to $68.9 \%$ in 2018 . Since 2018 , the situation with the implementation of vaccinations has improved significantly. However, the powerful layer of immunologically diphtheria unprotected population of our region formed in recent years remained a serious factor in the possible development and spread of the diphtheria epidemic. (see Table I).

Due to the diphtheria outbreak in 2019, the implementation of diphtheria vaccination plans has increased significantly, including a significant percentage of diphtheria vaccination coverage in adults $(96.4 \%)$. In 2020 , there is a decrease in planned vaccination volume owing to the spread of the COVID-19 pandemic.

The study of the state of population immunity of the Transcarpathian region has been conducted from 1987 to 
Table I. Implementation of the consolidated plan of diphtheria vaccinations in the Transcarpathian region of Ukraine within 2010-2020

\begin{tabular}{|c|c|c|c|c|c|}
\hline \multirow{2}{*}{ Years } & \multirow{2}{*}{ Plan } & \multicolumn{2}{|c|}{ Executed } & \multicolumn{2}{|c|}{ Not fulfilled } \\
\hline & & $\mathbf{n}$ & $\%$ & $\mathbf{n}$ & $\%$ \\
\hline 2010 & 121527 & 61344 & 50,5 & 60183 & 49,5 \\
\hline Adult population & 52135 & 14340 & 27,5 & 37795 & 72,5 \\
\hline 2011 & 167596 & 39151 & 23,4 & 128445 & 76,6 \\
\hline Adult population & 83811 & 7800 & 9,3 & 76011 & 90,7 \\
\hline 2012 & 228083 & 105719 & 46,3 & 122364 & 53,6 \\
\hline Adult population & 112581 & 41620 & 36,9 & 70961 & 63,0 \\
\hline 2013 & 127721 & 42657 & 33,4 & 85064 & 66,5 \\
\hline Adult population & 48168 & 7726 & 16,04 & 40442 & 83,9 \\
\hline 2014 & 132976 & 13060 & 9,8 & 119916 & 90,2 \\
\hline Adult population & 47352 & 854 & 1,8 & 46498 & 98,2 \\
\hline 2015 & 169351 & 12144 & 7,2 & 157207 & 92,8 \\
\hline Adult population & 36499 & 0 & 0 & 36499 & 100,0 \\
\hline 2016 & 218487 & 34030 & 15,7 & 184457 & 84,3 \\
\hline Adult population & 53210 & 1963 & 3,7 & 51247 & 96,3 \\
\hline 2017 & 252551 & 95093 & 37,7 & 157458 & 62,3 \\
\hline Adult population & 103294 & 39665 & 38,5 & 63629 & 61,5 \\
\hline 2018 & 160998 & 93675 & 58,1 & 67323 & 41,9 \\
\hline Adult population & 49736 & 34284 & 68,9 & 15452 & 31,2 \\
\hline 2019 & 215560 & 174391 & 80,9 & 41169 & 19,1 \\
\hline Adult population & 89327 & 86096 & 96,4 & 3231 & 3,6 \\
\hline 2020 & 198974 & 77514 & 38,9 & 121460 & 61,1 \\
\hline Adult population & 87861 & 27339 & 31,1 & 60552 & 68,9 \\
\hline
\end{tabular}

2003 by assessment of the titers of diphtheria antibodies in blood serum. Unfortunately, further studies were done in insufficient volumes for statistically significant conclusions. We reveled two waves of rising levels of vulnerability to this infection within this period. In $199023.9 \%$ of the population had immune defense against diphtheria and $25.7 \%$ in 1994 . Comparison of the state of immunity with diphtheria incidence dynamics revealed a pattern: the years with the highest percentages of immunologically vulnerable population preceded the increase in diphtheria incidence: in 1991 - 35 cases; in 1992 - 61; in 1993 - 40 cases. The second peak of population insecurity preceded by an outbreak of diphtheria in 1995 - 79 cases.

With the introduction of preventive vaccinations against diphtheria in the Transcarpathian region in the 50-60 years of the last century, the infection gradually ceased to be childhood. Analysis of the age structure of the prevalence, carriage and morbidity of diphtheria during the epidemic of the '90s shows slight differences in the incidence of children and adults: the proportion of children was $52.2 \%$, adults $-47.8 \%$. Regarding the carrier of diphtheria pathogens, $58.3 \%$ of the detected carriers were children, and $41.7 \%$ were adults. The characteristics of the age distribution of patients during the epidemic of the ' $90 \mathrm{~s}$ were as follows: adult population $67.5 \%$, children under 14 years $-32.5 \%$.
According to the retrospective analysis results, despite many years of mass vaccine prophylaxis, diphtheria has retained the periodicity and seasonality characteristic of the pre-vaccination era. Analysis of seasonality of incidence diphtheria for the epidemic period of 1990-2000 in the Transcarpathian region shows an uneven annual distribution of morbidity and the manifestation of the characteristic autumn-winter seasonality: $64 \%$ of registered cases were registered in the period from November to April.

\section{CONCLUSIONS}

At the present stage, diphtheria's epidemic process in the Transcarpathian region is characterized by the following features. Namely, a long period with a minimal level of morbidity and its absence during 2012-2018 (the last case was detected in 2011), followed by an epidemic outbreak in 2019. The Surveillance Service registered the minimum level of carriers of mainly nontoxigenic diphtheria strains in the absence of registration of the disease. A significant reduction in the volume of preventive vaccinations against diphtheria is characteristic for last decade in all age groups. Low coverage of the population with vaccination against diphtheria, registration of an outbreak of diphtheria among international students of the region, and in other regions of Ukraine in conditions of increased population migration, 
are alarming prognostic signs of the possible development of another significant epidemic rise of diphtheria morbidity in Transcarpathia.

The results of the analysis of the diphtheria epidemic leading risk factors indicate the need for timely, comprehensive implementation of measures to prevent and combat this infection.

\section{REFERENCES}

1. Wagner K.S., White J.M., Lucenko I. et al. Diphtheria in the postepidemic period, Europe, 2000-2009. Emerg. Infect. Dis. 2012;18(2):217-225.

2. Sharma N.C., Efstratiou A., Mokrousov I. et al. Diphtheria. Nat Rev Dis Primers. 2019; 5:81. https://doi.org/10.1038/s41572-019-0131-y.

3. Murhekar M. Epidemiology of diphtheria in India, 1996-2016: implications for prevention and control. Am J Tropical Med Hyg. 2017;97(2):313-318. doi: 10.4269/ajtmh.17-0047.

4. Besa N. C., Coldiron M. E., Bakri A. et al. Diphtheria outbreak with high mortality in northeastern Nigeria. Epidemiol. Infect. 2013;142(4):797802. doi: $10.1017 / 50950268813001696$.

5. Rahman M. R., Islam K. Massive diphtheria outbreak among Rohingya refugees: lessons learnt. J Travel Med. 2019;26(1). doi: 10.1093/jtm/ tay122.

6. Dureab F., Al-SakkafM., Ismail 0. et al. Diphtheria outbreak in Yemen: the impact of conflict on a fragile health system. Confl Health. 2019;13:19. doi: 10.1186/s13031-019-0204-2.

7. Raad I. I., Chaftari A.-M., Dib R.W. et al. Emerging outbreaks associated with conflict and failing healthcare systems in the Middle East. Infect Control Hosp Epidemiol. 2018;39(10):1230-1236. doi: 10.1017/ ice.2018.177.

8. World Health Organization. Diphtheria vaccine:WHO position paper August 2017. Wkly Epidemiol Rec. 2017;92(31):417-35.

9. Rengganis I. Adult diphtheria vaccination. Acta Med Indonesia. 2018;50(3):268-272.

10. van Dam A. P., Schippers E.F., Visser L.G. et al. A case of diphtheria in the Netherlands due to an infection with Corynebacterium ulcerans. Ned Tijdschr Geneeskd. 2003;147(9):403-406.

11. Kolesnikova I.P., Mokhort H.A., Kolesnikov M.M. et al. Zahalna otsinka stanu zakhvoriuvanosti na vaktsyno kerovani infektsii v Ukraini (19442014 rr.), za osnovnymy epidemiolohichnymy kryteriiamy. Medychna nauka Ukrainy. 2016;12(1-2):64-71. (In Ukrainian).

12. WHO Vaccine-Preventable Diseases: Monitoring System. 2008 Global Summary. Immunization, Vaccines and Biologicals. World Health Organization. Geneva, Switzerland; 2008, 385 p.

13. Ukrayinske suspilstvo: migracijnij vimir. Nacionalna dopovid /Institut demografiyi ta socialnih doslidzhen im. M. V. Ptuhi NAN Ukrayini. Kiyiv; 2018, 396 p. (In Ukrainian).
14. Bachinska M. V., Baranyak I. Ye. Suchasni tendenciyi migracijnoyi aktivnosti naselennya karpatskogo regionu .Ekonomika ta derzhava. 2019;12:71-76. (In Ukrainian).

15. Kozlova I.A., Mokhort H.A., Nosenko H.A. et al. Epidemiolohichne znachennia vyiavlennia korynebakterii dyfterii v m. Kyievi v period aktyvizatsii epidemichnoho protsesu (1989-1998rr.). Suchasni infektsii. 2000;4:25-30. (In Ukrainian).

16. Mokhort H.A. Proiavy epidemichnoho protsesu dyfterii v suchasnykh umovakh i shliakhy udoskonalennia epidemiolohichnoho nahliadu. AMN Ukrayini. In-t epidemiologiyi ta infekc. hvorob im. L.V.Gromashevskogo. Avtoreferat dys. k.m.n. Kiyiv; 2003, 20 p. (In Ukrainian).

17. Podavalenko A.P. Estimating the Complication Risk of Epidemic Situation with Diphtheria in Ukraine. Asian Journal of Epidemiology. 2018;11(1):26-33.

18. Zaslavska G.0., DmitrukV.I. Dosyagnennya ta problemi imunoprofilaktiki infekcijnih zahvoryuvan u ditej na suchasnomu etapi. Pereshkodi $v$ provedenni imunizaciyi naselennya. Aktualna infektologiya. 2017;5(5):200-204. (In Ukrainian).

\section{ORCID and contributionship:}

Yelyzaveta I. Rubtsova: 0000-0001-9395-1822 ${ }^{A, B, D}$

Svitlana V. Oberemko: 0000-0003-1107-7938 B,C,F

Maryana M. Rosul: 0000-0002-2106-5386 C,F

\section{Conflict of interest:}

the Authors declare no conflict of interest.

\section{CORRESPONDING AUTHOR Yelyzaveta I. Rubtsova \\ Uzhgorod National University \\ 14 Universitetskaya St., 88000 Uzhgorod, Ukraine \\ tel: +380509277849 \\ e-mail:eli.rubtsova@cmail.com}

Received: 29.10 .2020

Accepted: 01.03 .2021

A - Work concept and design, B - Data collection and analysis, C - Responsibility for statistical analysis,

D-Writing the article, $\mathbf{E}$-Critical review, $\mathbf{F}$ - Final approval of the article 